\title{
Extraction and Application of Eco- Friendly Natural dye Obtained from Flower of Acacia eburnea (L.f.) Willd on Cotton Fabric
}

\author{
S Thiyagarajan, K Balakrishnan*, R Venkadachalam \\ Department of Chemistry, A. V. V. M. Sri Pushpam College, Thanjavur, India
}

Received: August 20, 2016; Accepted: September 10, 2016; Published: September 30, 2016

*Corresponding author: Dr K Balakrishnan M.Sc, M.Phil, B.Ed, Ph.D, Associate professor, Department of chemistry, A. V. V. M. Sri Pushpam College, Poondi, Thanjavur, Tamilnadu-613503, Tel: 9443564231; E-mail: balki63@gmail.com

\begin{abstract}
In this present study ethanalic dye extracts of Acacia eburnea (L.f.) Willd was dyed to the bleached cotton fabrics were dyed with different chemical mordant's using pre-mordanting, postmordanting and simultaneous-mordanting method. In this method post mordanting of ferrous sulphate compound gave good $\mathrm{K} / \mathrm{S}$ -value than others. The dyed fabrics have show good washing, light, rubbing fastness and perspiration fastness properties. Antimicrobial activities of the dye extract were also studied.
\end{abstract}

Keywords: Extraction; Natural Dyes; Acacia Eburnea (L.F.) Willd Flowers; ISO Method; Cotton; Textiles

\section{Introduction}

The natural dyes are using coloring agent of textile, food and paints in the beginning of the mankind. But synthetic dyes are removing colour in process in anything about one century back use of natural dyes have witnessed diminished. During last two decades natural dyes have witnessed a process of revival [1]. With the increasing awareness of government also helped us and far eco textiles and need to preserve environment has lead to the revival of old practice of coloration with natural dyestuff. Due to the carcinogens what natural of some synthetic dyes and their intermediates are being looked it is not effect natural dye and not damage included water and sand at as an "eco solution" to the ill effects of synthetic dyes. The serious limitation associated within the natural dyes is the process of dyeing with natural dyes in very lengthy and time consuming. Moreover reproducibility of shades is also a major problem faced in dyeing with natural dyes as traditional processes for their application on various substrates have been lost in the absence of proper documentation and years of neglect. Synthetic dyes are effect hair and skin problem and food items. It becomes necessary to develop new techniques of coloration and also to standardize these processes with the help of modern scientific so that these dyes can offer themselves as an effective eco option [2]. Natural dyes are known for their use in coloring of food substrate, leather, wood as well as natural fibers like wool, silk, cotton and flax as major areas of application since ancient times. Natural dyes may have a wide range of shades, and can be obtained from various parts of plants and synthesis dyes are fully chemical components. Since the advent of widely available and cheaper synthetic dyes in 1856 having moderate to excellent colour fastness properties is polluted eco system so natural dye was used for dyeing on cotton fabric. In, recently there has been revival of the growing interest on the application of natural dyes on natural fibers due to all over worldwide environmental consciousness [3]. In many of the world's developing countries, natural dyes can offer not only rich and varied source of dye stuff, it used income and through sustainable harvest and sale of these plants [4]. Today due to global environmental awareness trend of using natural colours is drawing production and application of synthetic dyes release large amount of waste and unwanted colour and causing health hazards environmental pollution and disturb eco - balance. The most alarming and affect to health due to the presence of toxic chemicals in the finished textiles especially which are coming in contact with the skin has opened new challenges for the persons working in the field of textiles industry [5]. Natural dyes have better biodegradability with the environment. They are nontoxic non - allergic to skin non - carcinogenic, easily available and renewable. Colour fastness is the resistance of a material to change any of its colour characteristic is extent of transfer of its colorants to adjacent which materials in touch generally light fastness, wash fastness and rub fastness are considered far textile fibers but synthesis are not biodegradability with environmental allergy [6].

Acacia eburnea (L.f.)Willd a small tree with red-purple corolla and yellow stamens and large ivory-white thorns, the pods papery, the leaf lets. Plant Name Acacia eburnea (L.f.) Willd. Family Fabaceae.

\section{Methods \\ Plant collection}

Acacia eburnea (L.f.) Willd flowers was collected from pannavayal village, Thanjavur district and authenticated by Dr. S John Britto, Rapinat Herbarium, St.josephs College, and Trichy. 


\section{Fabric}

For the cotton fabric bleaching process M: L ratio 1:30 is used. $1 \mathrm{~g}$ of cotton fabric sample has been taken in $100 \mathrm{ml}$ of beaker. 6 volumes $(20 \mathrm{ml})$ of $\mathrm{H}_{2} \mathrm{O}_{2}, 5 \mathrm{mlof} 4 \% \mathrm{NaOH}$ and $5 \mathrm{ml}$ of $2 \%$ sodium silicate are added with the fabric. 3 drops of wetting reagent is added to this solution and heated about $80-85^{\circ} \mathrm{C}$ for 1 hours. The cotton samples have been dried.

\section{Mordants}

Chemical used: AR grade metallic salts such as copper sulphate, ferrous sulphate, aluminium sulphate, Potassium diChromate, stannous Chloride were used as chemical mordant's

\section{Experimental}

Dye Extraction: Above 300 g of Acacia eburnea (L.f.) Willd fresh flowers and added with $(80 \%$ of ethanol $+20 \%$ water ) and socking 15 minutes, $500 \mathrm{ml}$ of RB flask and highly heated to 60 minutes at $70^{\circ} \mathrm{C}$. Then transferred to after extractions were filtered and used as a natural dye. It was noticed that, colour of the dye extract was brownish yellow colour.

\section{Effect of M: L Ratio}

Weighed cotton samples were dyed with dye extracts keeping in the $\mathrm{M}$ : $\mathrm{L}$ ratio of 1:10, 1:20, 1:30 and 1:40. Its indicate that $\mathrm{M}: \mathrm{L}$ ratio $1: 30$ is the better dyeing. Compare with others.

\section{Dyeing procedure}

Weighed cotton samples were dyed with dye extract maintenance $\mathrm{M}$ : $\mathrm{L}$ ratio as $1: 30$ dyeing was carried out at $78^{\circ} \mathrm{C}$ and continued for 1 hour.

\section{Mordanting}

Weighed cotton samples were treated and with different chemical mordant's by following three methods [7].

(i) pre- mordanting

(ii) simultaneous mordanting

(iii) post- mordanting

\section{Pre Mordanting of cotton cloth with metallic salts}

Bleached cotton cloth with pre mordanting were added to dyeing of following any one chemical mordant's, such as $\mathrm{K}_{2} \mathrm{Cr}_{2} \mathrm{O}_{7}$, $\mathrm{Al}_{2} \mathrm{SO}_{4}, \mathrm{CuSO}_{4}, \mathrm{SnCl}_{2}$, and $\mathrm{FeSO}_{4}$ at $60^{\circ} \mathrm{C}$ for $30 \mathrm{~min}$. And mordant cloth and added with natural flower extract and added some amount of water and heated. After 10 minutes added required amount of sodium carbonate. After 20 minutes added required amount of sodium chloride was added, 1 hour heated at $78^{\circ} \mathrm{C}$ with M:L ratio of 1:30 then it is added to the flowers extract. The dyed cloth were again washed with water and then dried in air.

\section{Simultaneous Mordanting of cotton cloth with metallic salts}

Bleached cotton cloth with natural dye extract and, using any one of the chemical mordant's, such as $\mathrm{K}_{2} \mathrm{Cr}_{2} \mathrm{O}_{7}, \mathrm{Al}_{2} \mathrm{SO}_{4}, \mathrm{CuSO}_{4}$ $\mathrm{SnCl}_{2}$ and $\mathrm{FeSO}_{4}$ added some amount of water. After 10 minutes added required amount of sodium carbonate. After 20 minutes added required amount of sodium chloride was added, 1 hour heated at $78^{\circ} \mathrm{C}$ with $\mathrm{M}: \mathrm{L}$ ratio of $1: 30$. The dyed cloth were again washed with water and then dried in air.

\section{Post Mordanting of cotton cloth with metallic salts}

Bleached cotton cloth with natural dye extract and, added some amount of water and heated. 1 hour heated at $78^{\circ} \mathrm{C}$. And natural dyed cloth and any one of the chemical mordant's, such as $\mathrm{K}_{2} \mathrm{Cr}_{2} \mathrm{O}_{7} \mathrm{Al}_{2} \mathrm{SO}_{4}, \mathrm{CuSO}_{4} \mathrm{SnCl}_{2}$ andFeSO $\mathrm{F}_{4}$ at After 10 minutes added required amount of sodium carbonate. After 20 minutes added required amount of sodium chloride was added, 30 minutes heated at $60^{\circ} \mathrm{C}$ with $\mathrm{M}: \mathrm{L}$ ratio of $1: 30$. The dyed cloth were again washed with water and then dried in air.

\section{Color fastness}

The colour fastness were determined washing, light, rubbing and perspiration methods of standards methods. ISO - 105- C06: 2010, ISO 105- BO2: 2014, IS: 766-1956, and ISO-E04:2013 respectively [8].

\section{Measurement of colour strength}

The colour strength of the dyed cotton fabrics were determined by K/S values. The light reflectance of the dyed cotton samples were measured using a Text flash spectrophotometer (Data colour corp.). The K/S values were calculated by KubelkaMunk equation.

\section{$K / S=(1-R)^{2} / 2 R$}

Where, $\mathrm{R}$ is the decimal fraction of the light reflectance of the dyed samples at max. $\mathrm{K}$ is the absorption coefficient and $\mathrm{S}$ is scattering coefficient [9].

\section{Antimicrobial Screening Test}

The antimicrobial (both bacterial and fungal) studies were carried out in duplicates using agar well diffusion method and a control set was along with each test to determine the antimicrobial activity. Investigations were carried out to determine the antibacterial activity of the dye solution $50 \mathrm{mg} /$ $\mu \mathrm{l}^{10}[10]$.

Pathogenic micro organisms were purchased from Trichy Medical College Pathology Departments. The test bacteria staphylococcus aureus ATCC 25923, Escherichiacoli ATCC 25922, Pseudomonas aeroginosa ATCC 27853. Pathogenic bacteria culture in nutrient broth at $37^{\circ} \mathrm{C}$ for $24 \mathrm{hrs}$ the culture were swapped on nutrient agar plates $100 \mu$ l of the dye solution loaded in the well after incubation $37^{\circ} \mathrm{c}$ for 24 hours the zone of inhibition was measured by the taking the average of the zone obtained from the duplicate plates [11]. Anti fungal activity of the dye against Aspergillusniger and Candida albicans have been detected on sterile potato dextrose agar plates. Concentration of the dye in a similar way as described above. After incubation at between $37^{\circ} \mathrm{C}$ for $72 \mathrm{hrs}$ the zone of inhibition was measured.

\section{Result}

The post mordanting method is shown in Figure -1 .

'The effect of mordant's on colour values of cotton fabric dyed 
Extraction and Application of Eco- Friendly Natural dye Obtained from Flower of Acacia eburnea (L.f.)Willd on Cotton Fabric

with Acacia eburnea (L.f.)Willd flowers is shown in Figure-2 and concerned Table-1.

The fastness properties of dyed of cotton fabrics are shown in Table-2.

Antibacterial and antifungal activity as are shown in Figure-3 and concerned Table- 3

\section{Discussion}

\section{Effect of Mordanting}

The natural dye extract was found to be suitable for cotton fabric. The cotton fabrics were dyed with chemical mordant's. It was observed that, the dye uptake was found to excellent.

\section{Optimization of mordant's with $\mathrm{K} / \mathrm{S}$ value and colour hue change}

The different mordant's not only cause difference in hues of colour and significant changes in $\mathrm{K} / \mathrm{S}$ values but also changes in $\mathrm{L}^{*}$ Values and brightness index value.

$\mathrm{L}^{*}, \mathrm{a}^{*}, \mathrm{~b},{ }^{*} \mathrm{C}{ }^{*}, \mathrm{H}^{*}$ and colour strength $\mathrm{K} / \mathrm{S}$ values and it can be seen that, mordant's which show higher value of $L^{*}$ show lighter shades while lower $L^{*}$ value show darker shades for. Furthermore, negative values of $\mathrm{a}^{*}$ and $\mathrm{b}^{*}$ appearance green and

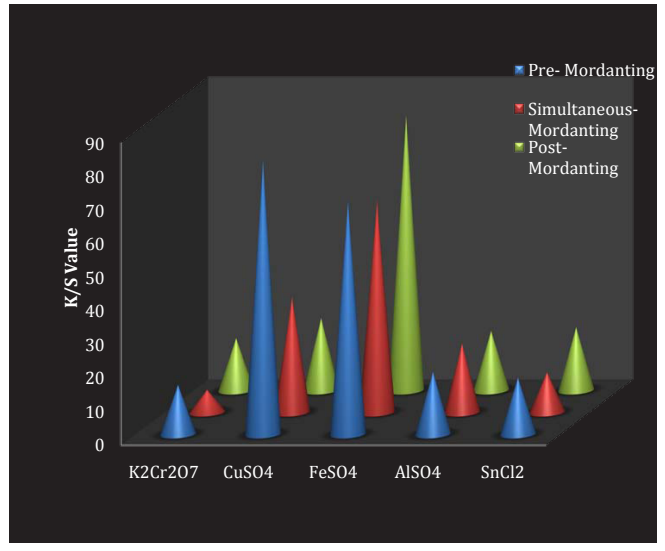

Figure 1: Surface colour strength (K/S values) of dyed cotton fabrics after pre, post and simultaneous Mordanting.

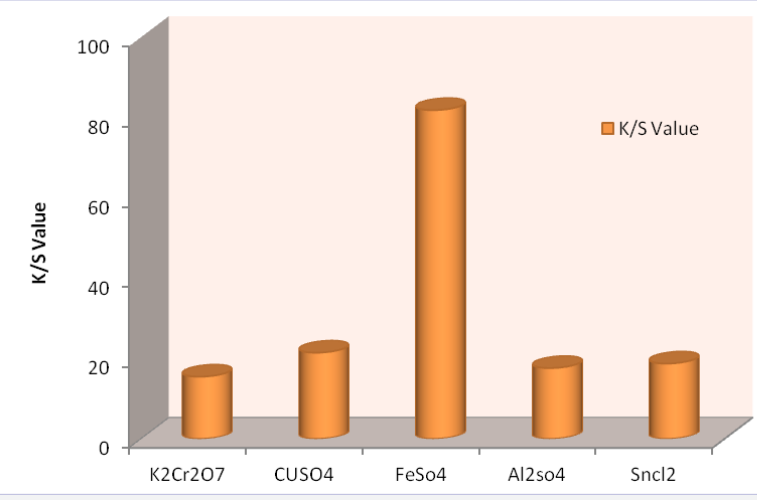

Figure 2: Effect of Mordants on colour Values of cotton fabric with Flowers of Acacia eburnea (L.f.) Wild (Post-Mordanted).
Copyright:

(C) 2016 Balakrishnan, et al.

Table-1: Different Post mordant's $\mathrm{L}^{*}, \mathrm{a}^{*}, \mathrm{~b},{ }^{*} \mathrm{C}^{*}, \mathrm{H}^{*}$ and $\mathrm{K} / \mathrm{S}$ Values for cotton fabric dyed with Acacia eburnea (L.f.)Willd(flowers)

\begin{tabular}{|l|l|c|c|c|c|c|l|}
\hline S.NO & Mordants & $\mathbf{L}^{*}$ & \multicolumn{1}{|c|}{$\mathbf{a}^{*}$} & $\mathbf{b}^{*}$ & $\mathbf{C}^{*}$ & $\mathbf{H}^{*}$ & $\begin{array}{l}\text { K/S } \\
\text { Value }\end{array}$ \\
\hline 1 & $\mathrm{~K}_{2} \mathrm{Cr}_{2} \mathrm{O}_{7}$ & 73.079 & 1.884 & 21.375 & 21.458 & 84.031 & 15.461 \\
\hline 2 & $\mathrm{CuSO}_{4}$ & 68.709 & 1.566 & 22.083 & 22.138 & 85.909 & 21.445 \\
\hline 3 & $\mathrm{FeSO}_{4}$ & 44.880 & 1.897 & 7.578 & 7.812 & 75.915 & 81.868 \\
\hline 4 & $\mathrm{Al}_{2} \mathrm{SO}_{4}$ & 73.360 & -1.093 & 28.437 & 28.458 & 92.236 & 17.607 \\
\hline 5 & $\mathrm{SnCl}_{2}$ & 71.136 & 1.622 & 25.082 & 25.134 & 86.265 & 18.727 \\
\hline
\end{tabular}

Table-2: Fastness properties for cotton fabric dyed with Acacia eburnea (L.f.) Willd (flowers)

\begin{tabular}{|c|c|c|c|c|c|c|c|c|c|c|}
\hline \multirow[t]{3}{*}{ S.NO } & \multirow[t]{3}{*}{$\begin{array}{l}\text { Mordant } \\
\text { Proportions }\end{array}$} & \multirow{3}{*}{$\begin{array}{l}\text { Light } \\
\text { Fastness } \\
\text { Grades } \\
\text { (ISO - } \\
\text { 105- C06 } \\
\text { : 2010) }\end{array}$} & \multirow{2}{*}{\multicolumn{2}{|c|}{$\begin{array}{l}\text { Washing } \\
\text { Fastness } \\
\text { Grades( } \\
\text { ISO 105- } \\
\text { B02: } \\
\text { 2014) }\end{array}$}} & \multirow{2}{*}{\multicolumn{2}{|c|}{$\begin{array}{l}\text { Rubbing } \\
\text { Fastness } \\
\text { Grades(ISO: } \\
\text { 766-1956) }\end{array}$}} & \multicolumn{4}{|c|}{$\begin{array}{l}\text { Perspiration } \\
\text { Fastness(ISO : } \\
\text { E04 : 2013) }\end{array}$} \\
\hline & & & & & & & Acid & & Alk & raline \\
\hline & & & $\mathrm{CC}$ & CS & Dry & Wet & $\mathrm{CC}$ & CS & $\mathrm{CC}$ & CS \\
\hline 1 & $\mathrm{~K}_{2} \mathrm{Cr}_{2} \mathrm{O}_{7}$ & 3 & 3-4 & $4-5$ & 4 & 3-4 & $4-5$ & 4-5 & $4-5$ & $4-5$ \\
\hline 2 & $\mathrm{CuSO}_{4}$ & 3-4 & $2-3$ & $4-5$ & 4 & 4 & $2-3$ & $4-5$ & 3 & $4-5$ \\
\hline 3 & $\mathrm{FeSO}_{4}$ & 4 & 4 & $4-5$ & $4-5$ & 4 & $4-5$ & $4-5$ & $4-5$ & $4-5$ \\
\hline 4 & $\mathrm{Al}_{2} \mathrm{SO}_{4}$ & 2 & 3 & $4-5$ & 4 & 4 & $2-3$ & $4-5$ & $3-4$ & $4-5$ \\
\hline 5 & $\mathrm{SnCl}_{2}$ & 3 & 3-4 & 4-5 & 4 & 4 & 4 & $4-5$ & $4-5$ & 4-5 \\
\hline
\end{tabular}

\section{Zone of inhibition}

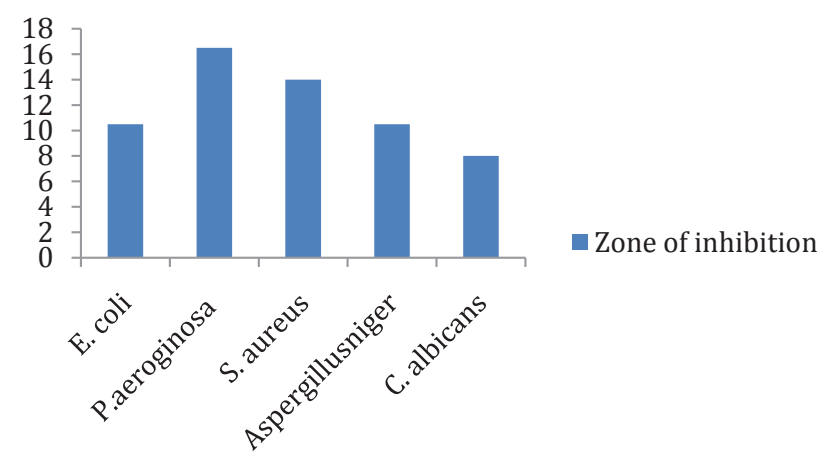

Figure 3: Antimicrobial activities of dye extract from flowers of Acacia eburnea (L.f.)Willd (flowers).

Table-3: Antimicrobial activities of natural dye extract from Acacia eburnea (L.f.)Willd (flowers)

\begin{tabular}{|l|l|l|}
\hline Micro organism & Test Culture & $\begin{array}{l}\text { Diameter Zone of inhibition } \\
(\mathbf{m m})\end{array}$ \\
\hline & Escherichia coli & \\
bacteria & $\begin{array}{l}\text { Pseudomonas } \\
\text { aeroginosa } \\
\text { Staphylococcies } \\
\text { aureus pathogens }\end{array}$ & 10.5 \\
\hline fungal & Aspergillusniger & 16.5 \\
\hline & Candida albicans & 8 \\
\hline
\end{tabular}


blue properly $\mathrm{C}^{*}$ chromaticity $\mathrm{H}^{*}$ hue of the colour. Among the chemical mordant's used, the highest colour value $(\mathrm{K} / \mathrm{S}=81.868)$ was obtained with $\mathrm{FeSO}_{4}$ and lowest colour value $(\mathrm{K} / \mathrm{S}=15.461)$ with $\mathrm{K}_{2} \mathrm{Cr}_{2} \mathrm{O}_{7}$

\section{Fastness properties}

It was observed that, dyeing with Acacia eburnea (L.f.)Willd has excellent washing, lighting, rubbing and perspiration fastness properties. Overall, it could be used for commercial purposes and attain acceptable range.

\section{Antimicrobial Activity Studies}

In this study, three different bacterial and two fungal pathogens were used to screening the possible antimicrobial activity of dye extract. Natural dye extract exhibited antibacterial and antifungal activity against all test microorganisms.

\section{Antibacterial and antifungal activity}

The natural dye extract showed good antibacterial activity against the three bacterial pathogens. Dye extract showed more effective against Escherichia coli, Pseudomonas aeroginosa and Staphylococcus aureus pathogens. The natural dye extract showed good antifungal activity against the two antifungal. Dye extract showed more effective against Aspergillusniger, Candida albicans.

\section{Conclusion}

The natural dye shows non-toxic non-allergic effects and results in less pollution as well as less side effects, it become a thrust area in the field textile dyeing research. The flower extract of Acacia eburnea (L.f.)Willd has a good natural dye source. The washing, lighting, rubbing and perspiration fastness of all dyeing with mordant's were quit good and also dye extract has shown good antimicrobial activity. From the comparative study the fastness properties of dyed cotton samples gave a better result in the Post mordanting method. These are grown through under and so are easily available.

\section{References}

1. Gulrajani ML. Introduction to natural dyes. IN: Gulrajani, ML and Gupta DEd. IIT, Delhi. Natural Dyes and their Applications to Textiles. 1992;1-7.

2. Yadav Saroj, Rose Neelam, Singh Jeet Saroj, Khambra Krishna. Natural dye powder: an easy technique for eco - dyeing Research Journal of Recent Sciences. 2013;2(ISC-2012):308-311.

3. Ashis Kumar Samanta and Priti Agarwal. Ashis Kumar Samanta and Priti Agarwal. Indian Journal of Fibre and textile Research. Indian Journal of Fibre and textile Research. 2009;34:384-399.

4. GW Taylor. Natural dyes in textile application. Review of progress in colouration and Related Topics. 1986;16:53-61. DOI: 10.1111/j.14784408.1986.tb03744.x

5. Anjali Deshmukh. Colour gamut of holarrhena antidysentrica linn. Dyed silk. RMUTP International Conference. Textiles \& Fashion. 2012;3-4.

6. Kulkarni SS, Gokhale AV, Bodake UM, and Pathade GR. Cotton dyeing with Natural Dye Extracted from Pomegranate Peel. Universal Journal of Environmental Research and Technology. 2011;1(2):135-139.

7. S Thiyagarajan, K Balakrishnan, S Tamilarasi. Eco-friendly dyeing of cotton fabric with a natural dye extracted from flowersof Dichrostachys cinerea Advances in Applied Science Research. 2015;6(11):68-75. ISSN: 0976-8610

8. Vankar PS, Shanker R, Dixit S. Sonicator dyeing of cotton with the leaves extract Acer pectinatum Wallich. Pigment \& Resin Technology. 2008;37(5):308-313. ISSN 0369-9420.

9. S Habibzadeh, H Tayebi, E Eerami, A Shams Nateri, M Allahnia and M.Bahmai. silk Dyeing Using Saw- Wood of the Zelkoa Forest Tree. World Applied Journal. 2010;9(3):295-299.

10. Singh R, Jain A, Panwar S, Gupta D and Khare SK. Antimicrobial activity of some natural dyes. Dyes Pigments. 2005;66:99-102. doi:10.1016/j. dyepig.2004.09.005. 